\title{
FAKTOR-FAKTOR YANG MEMPENGARUHI PERLU DILAKUKAN KEBIJAKAN REGULASI DALAM PENANGGULANGAN TIN-DAK PIDANA DI BIDANG PERBANKAN
}

\author{
Oleh : \\ M. Zen Abdullah * \\ Ibrahim* \\ Iman Hidayat *
}

\begin{abstract}
ABSTRAK
Secara kasat mata dalam praktiknya modus operandi tindak pidana di bidang perbankan kian hari terus- menerus meningkat, baik dari sisi kualitas maupun kuantitasnya. Bukan hanya dilakukan oleh orang yang berada di luar bank. Namun demikian juga dapat dilakukan oleh orang di dalam bank itu sendiri dan dapat pula terjadi kerja sama antara orang dalam maupun orang di luar bank, yang menjadikan bank sebagai sararan/objek dan sarana untuk melakukan kejahatan. Tindak pidana di bidang perbankan, walaupun sudah ada kebijakan regulasi yang menga-tur dan memberikan ancaman sanksi pidana terhadap pelakunya, baik yang termu-at di dalam Undang- undang Perbankan Nomor 7 Tahun 1992 yang diperbaharui dengan Undang- undang Nomor 10 Tahun 1998 maupun di luar Undang- undang Perbankan,yang berkaitan dengan kegiatan perbankan lainnya, seperti tindak pidana pemalsuan warkat dan/ atau dokumen bank dalam pemberian kredit,penipuan, pengge-lapan dana nasabah, penyalahgunaan wewenang/jabatan dan lainnya, yang sudah banyak pelaku tindak pidana di bidang perbankan yang dijerat dan divonis pidana. Permasalahannya, tindak pidana di bidang perbankan kenyataannya terusmenerus menunjukkan peningkatan kualitas maupun kuantitasnya, sehingga perlu dilakukan upaya menga-tasinya. Hal inilah yang menarik perhatian penulis untuk melakukan penelitian tentang "Faktor- faktor apakah yang mempengaruhi perlu dilakukan kebijakan regulasi dalam penanggulangan tindak pidana di bidang perbankan", dengan bahasan dilihat dari faktor internal dan faktor ekternal perlu dilakukan kebijakan regulasi dalam penanggulangan tindak pidana di bidang perbankan.
\end{abstract}

Kata Kunci : Kebijakan Regulasi, Tindak Pidana di Bidang Perbankan

\section{A. Latar Belakang}

Pembangunan Nasional tidak akan dapat dicapai dengan baik tanpa didukung dengan pembangunan ekonomi, pembangunan ekonomi hanya dapat berjalan dengan lancar apabila ditunjang dengan keberadaan industri perbankan. Keberadaan industri perbankan dalam kehidupan masyarakat dewasa ini, mempunyai peran yang cukup penting, karena industri perbankan merupakan wadah menyimpan dana dan sebagai sarana dalam

\footnotetext{
* Pengajar Program Magister Ilmu Hukum Unbari.

* Pengajar Program Magister Ilmu Hukum Unbari.

* Pengajar Program Magister Ilmu Hukum Unbari.
} 
melakukan berbagai transaksi keuangan dan dalam men-dorong dan menopang pertumbuhan perekonomian suatu negara. Hampir semua sektor usaha, yang meliputi sektor indutri besar, me-nengah, kecil, sektor perdagangan, pertanian, perkebunan, pertambangan, jasa dan perumahan sangat membutuhkan bank sebagai mitra dalam melakukan transaksi keuangannya.

Kontribusi yang besar dari industri perbankan sebagai lembaga perantara keuangan adalah dalam rangka meningkatkan pertumbuhan perekonomian nasional. Hal ini dapat dilihat dari meningkatnya peran intermediasi (perantara antara penyimpan dengan peminjam uang) dengan baik, dilihat dari sisi peningkatan asset, kredit dan dari sisi dana pihak ketiga, masing- masing tumbuh dengan angka sebesar 13,34\%, 11,58\% dan 12,29\%.

Peningkatan kinerja industri perbankan tersebut dilihat dari sisi internal yang disertai dengan perbaikan kualitas pertumbuhan yang tercermin dari tingginya peran investasi swasta, penurunan tingkat pengangguran dan kemiskinan serta pemerataan pertumbuhan ekonomi antar daerah yang semakin membaik. Sedangkan dari sisi eksternal, neraca pembayaran Indonesia mengalami surplus (kelebihan) dengan cadangan devisa yang meningkat dan nilai tukar rupiah yang mengalami apresiasi.

Perkembangan industri perbankan dengan memasuki era globalisasi dan liberalisasi pasar keuangan saat ini, telah mengakibatkan mening-katnya persaingan di antara bankbank terutama dalam penghimpunan dana. Untuk itu, manajemen bank dituntut mempunyai ketrampilan mengelola kekayaan, utang dan modal bank yang tercermin dalam neraca bank dengan baik. Suatu hal yang lebih mendasar dari keahlian dan ketrampilan tersebut adalah adanya itikad baik. Artinya, pengurus bank seharusnya adalah pihak yang selalu menjunjung tinggi kode etik perbankan dan mematuhi segala peraturan perundang- undangan di bidang perbankan yang berlaku.

Industri perbankan sebagai lembaga keuangan seringkali dihadapi dengan berbagai persoalan yang mendasar. Bukan hanya menghadapi persoalan internal yang menyangkut meminimalkan pengendalian ber-bagai manajemen risiko yang mungkin dan akan terjadi di lingkungan perbankan. Namun demikian, lebih dari itu industri perbankan dihadapi pula dengan beraneka ragam beban tugas dalam menjalankan kegiatan usaha perbankan. Beban tugas dimaksud, meliputi mulai dari kegiatan memasarkan produk penghimpunan dana melalui pemberian kredit hingga produk layanan jasa dalam kegiatan perbankan dalam bentuk transper (pengiriman uang) dan layanan pertukaran/jual beli valuta asing (money changer) hingga layanan menggunakan perbankan elektronik (electronic banking) yang 
mencakup ATM banking, kartu debit, kartu kredit, inkaso (layanan bank untuk penagihan pembayaran atas surat/dokumen berharga kepada pihak ketiga di tempat lain), referensi bank (keterangan dalam bentuk surat yang dikeluarkan oleh bank yang diberikan kepada seseorang atau badan usaha yang menjadi nasabahnya berisikan identitas seseorang atau badan usaha) dan lainnya.

Kompleks dan beragam serta variatifnya layanan produk dan laya-nan jasa- jasa perbankan yang ditawarkan dan dipasarkan industri per-bankan pada masyarakat, dengan jumlah dana yang dikelola aktivitas bisnis cukup besar, melibatkan banyaknya nasabah dari berbagai jenis produk, termasuk aktivitas penyaluran kredit yang bervariatif, dengan layanan- layanan jasa beragam, penggunaan tehnologi (electronic ban-king) yang jangkauannya cukup luas dan memudahkan dalam transaksi antar nasabah, lemahnya sistem pengawasan internal (internal control) yang dilakukan bank yang bersangkutan maupun pengawasan otoritas yang berwenang, adanya moral hazard (prilaku jahat), mengakibatkan industri perbankan rentan akan terjadi penyimpangan- penyimpangan/ penyalah-gunaan kewenangan yang mengarah pada perbuatan melanggar hukum, baik pelanggaran yang berakibat dijerat dan/ atau diterapkan sanksi per-data, sanksi administratif maupun yang berupa sanksi pidana yang berkaitan dengan menjalankan bisnis bank.

Sanksi pidana diatur dalam ketentuan pasal 46 hingga pasal 50A Undang- undang Perbankan Nomor 7 Tahun 1992 yang diperbaharui dengan Undang- undang Nomor 10 Tahun 1998, yang di dalamnya terdapat beberapa jenis tindak pidana perbankan, yaitu tindak pidana yang berkaitan dengan perizinan, tindak pidana yang berkaitan dengan rahasia bank, tindak pidana yang berkaitan dengan pengawasan dan pembinaan bank, tindak pidana yang berkaitan dengan usaha bank dan tindak pidana yang berkaitan dengan pihak teralifiasi.

Selain tindak pidana perbankan yang terdapat dan diatur dalam Undang- undang Perbankan Nomor 7 Tahun 1992 yang diperbaharui dengan Undang- undang Nomor 10 Tahun 1998, terdapat juga tindak pidana yang berkaitan dengan kegiatan perbankan lainnya, seperti tindak pidana pemalsuan warkat dan/ atau dokumen bank dalam pemberian kredit, tindak pidana penipuan, penggelapan dana nasabah dan lainnya yang diatur dalam pasal 263, pasal 264, pasal 372 dan pasal 374 Kitab Undang- undang Hukum Pidana (KUHP) Nomor 1 Tahun 1946. Penyalah-gunaan wewenang/jabatan sebagai direksi, pejabat dan pegawai bank dengan menerima imbalan, hadiah dan lainnya yang dijerat dan 
diatur dalam Undang- undang Pemberantasan Tindak Pidana Korupsi Nomor 31 Tahun 1999 yang diperbaharui dengan Undang- undang Nomor 20 Tahun 2001, tindak pidana yang berkaitan bank sebagai kustodian dan tindakan bank sebagai wali amanat, dimana bank tidak memiliki izin dan tidak terdaftar di pasar modal yang melanggar UndangUndang Pasar Modal Nomor 8 Tahun 1995, tindak pidana menyimpan uang hasil kejahatan (kejahatan korupsi, narkotika, perdagangan senjata gelap, perampo-kan) yang dananya ditempatkan di perbankan yang diatur dengan Undang- undang Pencegahan dan Pemberantasan Tindak Pidana Pencu-cian uang Nomor 25 Tahun 2003 yang diperbaharui dengan Undang- undang Nomor 8 Tahun 2010 dan lainnya.

Tindak pidana di bidang perbankan, walaupun sudah ada kebijakan regulasi yang mengatur dan memberikan ancaman sanksi pidana, baik yang termuat di dalam dan di luar Undang- undang Perbankan Nomor 7 Tahun 1992 yang diperbaharui dengan Undangundang Nomor 10 Tahun 1998. Begitu juga dalam penegakan hukum dan penerapan pidana sudah banyak pelaku tindak pidana di bidang perbankan yang dijerat dan divonis pidana. Secara kasat mata dalam praktiknya modus operandi tindak pidana di bidang perbankan kian hari terus- menerus meningkat, baik dari sisi kualitas maupun kuantitasnya. Bukan hanya dilakukan oleh orang yang berada di luar bank. Namun demikian juga dapat dilakukan oleh orang di dalam bank itu sendiri dan dapat pula terjadi kerja sama antara orang dalam maupun orang di luar bank, yang menjadikan bank sebagai sararan/ objek dan sarana dalam mela-kukan kejahatan.

Permasalahannya, menunjukkan tindak pidana di bidang perbankan terus- menerus terjadi dan cenderung meningkat, sehingga perlu dicari langkah antisipatif dalam upaya menguranginya, sehingga hal inilah yang menjadikan penulis tertarik untuk melakukan penelitian dengan judul "Faktor- faktor apakah yang mempengaruhi perlu dilakukan kebijakan regulasi dalam penanggulangan tindak pidana di bidang perbankan", dengan bahasan dilihat dari faktor internal dan faktor ekternal perlu dila-kukan kebijakan regulasi dalam penanggulangan tindak pidana di bidang perbankan.

\section{B. Perumusan Masalah}

Berdasarkan latar belakang masalah yang dipaparkan diatas, maka perumusan masalah yang dikemukakan adalah sebagai berikut:

1. Faktor- faktor internal apakah yang mempengaruhi perlu dilaku-kan kebijakan regulasi dalam penanggulangan tindak pidana di bidang perbankan? 
2. Faktor ekternal yang bagaimanakah yang mempengaruhi perlu dilakukan kebijakan regulasi dalam penanggulangan tindak pidana di bidang perbankan ?

\section{Metode Penelitian}

\section{Tipe Penelitian}

Mengacu pada perumusan masalah dan tujuan penelitian tersebut di atas, maka penelitian ini dilakukan dengan menggunakan penelitian hukum normatif. Penelitian hukum normatif mencakup penelitian terhadap asas-asas hukum, sistematika hukum, sinkronisasi hukum, dan sejarah hukum.

Penelitian normatif diambil sebagai pendekatan dalam penelitian ini karena yang menjadi perhatian utama adalah ketentuan perundang-undangan yang mengatur mengenai perbuatan pidana dan sanksi pidana penayangan siaran televisi yang dapat menyebabkan terjadinya kriminalitas di kalangan anak-anak.

2. Pendekatan yang Digunakan

Berdasarkan tipe penelitian normatif tersebut di atas, maka pendekatan yang digunakan dalam penelitian ini adalah pendekatan konseptual (conceptual approach), pendekatan perundang-undangan (normative approach) dan pendekatan sejarah (historical approach).

Terkait dengan pendekatan tersebut, dalam penelitian ini akan digambarkan tentang hal-hal yang berkaitan dengan perbuatan dan pertanggungjawaban pidana penyiaran.

Setelah bahan-bahan hukum tersebut terkumpul, maka dilakukan analisis dengan cara:

a. Menginterpretasikan semua peraturan perundang-undangan sesuai masalah yang dibahas.

b. Mengevaluasi peraturan perundang-undangan yang berhubungaı dengan masalah yang diteliti.

c. Menilai bahan-bahan hukum yang berhubungan dengan masalah yang dibahas.

\section{Faktor Internal Yang Mempengaruhi Perlu Dilakukan Kebijakan Regulasi Dalam Penanggulangan Tindak Pidana di Bidang Perban-kan}

Kebijakan regulasi diartikan sebagai suatu usaha untuk menyusun, merumuskan dan menetapkan suatu perundang- undangan pidana yang baik, yang dapat dijadikan sebagai pedoman tidak hanya kepada pembuat Undang- undang, tetapi juga kepada pengadilan 
yang menerapkan Un-dang- undang dan juga kepada penyelenggara negara atau pelaksana putusan pengadilan. ${ }^{1}$ Peraturan perundang- undangan yang baik, diha-rapkan dapat menanggulangi kejahatan dan khususnya tindak pidana di bidang perbankan yang semakin hari semakin berkembang terus baik kualitas maupun kuantitasnya.

Dalam mencegah dan menanggulangi tindak pidana di bidang per-bankan, di samping diperlukan peningkatan fungsi kontrol bank baik yang dilakukan internal bank maupun dari Bank Indonesia (sekarang Otoritas Jasa Keuangan) harus diperketat dan diperkuat dengan menen-tukan standar operasional yang baku, menjaga ketaatan tata cara dan proses dalam kegiatan perbankan, pengawasan terhadap manajemen dan menjaga secara ketat prinsif kehati- hatian dan standar moral dari pihak bank. ${ }^{2}$ Tidak kalah pentingnya adanya regulasi aturan perundang- un-dangan sebagai dasar hukum bagi aparat penegak hukum dalam pe-nanggulangan tindak pidana di bidang perbankan.

Faktor Internal yang mempengaruhi perlu dilakukan kebijakan regu-lasi dalam penanggulangan tindak pidana di bidang perbankan, yaitu dengan dikeluarkan dan atau ditetapkannya Undang- Undang Perbankan Nomor 7 Tahun 1992 yang diperbaharui dengan Undang- undang Nomor 10 tahun 1998.

Undang- undang Perbankan ini, memiliki peran yang sangat penting dalam mewujudkan suatu sistem perbankan nasional yang kuat, sehat dan tangguh. Di dalam Undang- undang Perbankan yang terdiri dari 10 Bab dan 60 pasal, diatur mulai dari azas, fungsi dan tujuan perbankan, jenis dan usaha bank, prihal perizinan, bentuk hukum dan kepemilikan, pembinaan dan pengawasan bank serta termasuk ketentuan pidana dan sanksi administratif.

Ketentuan pidana dan sanksi administratif yang dicantumkan dalam Bab VIII mulai pasal 46 hingga pasal 53 Undang- Undang Perbankan Nomor 10 Tahun 1998, ditujukan untuk mencegah dan menanggulangi dalam penyelenggaraan kegiatan industri di bidang perbankan dari praktik- praktik bisnis kotor, tercela dan menimbulkan kerugian bagi masyarakat yang terindikasi melawan hukum dan merupakan perbuatan pidana, maka terhadapnya dikenakan sanksi pidana. Sanksi pidana di dalam Undang- Undang Perbankan Nomor 10 Tahun 1998, dimuat dan diatur mulai dari pasal 46, 47, 47A 48, 49, 50 dan pasal

${ }^{1}$ Barda Nawawi Arief, Op, Cit, Halaman 23.

${ }^{2}$ Yenti Garnasih, Mei 2015, Materi Seminar 'Optimalisasi Penelusuran Hasil Tindak Pidana Perbankan' yang diselenggarakan LPS dan Jurnalis Indonesia, Jakarta, Halaman 12. 
50A, yang menggambarkan berbagai jenis tindak pidana perbankan seperti tertera dalam tabel berikut ini ;

Tabel 1

Jenis- jenis Tindak Pidana Perbankan Berdasarkan

Undang- undang Perbankan Nomor 10 Tahun 1998

\begin{tabular}{|c|l|l|}
\hline No & \multicolumn{1}{|c|}{ Jenis- jenis Tindak Pidana } & \multicolumn{1}{c|}{ Pasal } \\
\hline 1. & Tindak pidana yang berkaitan dengan perizinan & Pasal 46 \\
\hline 2. & $\begin{array}{l}\text { Tindak pidana yang berkaitan dengan rahasia } \\
\text { bank }\end{array}$ & Pasal 47 dan pasal 47A \\
\hline 3. & $\begin{array}{l}\text { Tindak pidana yang berkaitan dengan } \\
\text { pengawasan dan pembinaan bank }\end{array}$ & Pasal 48 \\
\hline 4. & $\begin{array}{l}\text { Tindak pidana yang berkaitan dengan usaha } \\
\text { bank }\end{array}$ & Pasal 49 \\
\hline 5. & $\begin{array}{l}\text { Tindak pidana yang berkaitan dengan pihak } \\
\text { teralifiasi }\end{array}$ & Pasal 50 dan pasal 50A \\
\hline
\end{tabular}

Sumber Data : Undang- undang Perbankan Nomor 10 Tahun 1998.

Dari berbagai jenis tindak pidana perbankan yang diutarakan di atas, yaitu tindak pidana yang berkaitan dengan perizinan, tindak pidana yang berkaitan dengan rahasia bank, tindak pidana yang berkaitan dengan pengawasan dan pembinaan bank, tindak pidana yang berkaitan dengan usaha bank serta tindak pidana yang berkaitan dengan pihak teralifiasi, yang diatur dalam ketentuan pasal 46 hingga pasal 50A. Apabila ditelusu-ri dan ditelaah ketentuan yang terdapat dalam rumusan pasal 46, 47, 47A, 48, 49, 50 dan pasal 50A Undang- undang Perbankan Nomor 10 Tahun 1998, di mana di dalamnya dapat dibedakan dan atau diklasifikasikan suatu perbuatan/ tindak pidana yang berupa kejahatan dan tindak pidana yang berupa pelanggaran, ${ }^{3}$ seperti terlihat perbedaannya pada tabel berikut ini ;

${ }^{3}$ Hermansyah, Op, Cit, Halaman 151. 
Tabel 2

\section{Penggolongan Tindak Pidana Perbankan Yang Berupa Kejahatan dan Pelanggaran Dalam Undang- undang Perbankan Nomor 10 Tahun 1998}

\begin{tabular}{|c|c|c|}
\hline No & $\begin{array}{l}\text { Penggolongan Tindak } \\
\text { Pidana Perbankan }\end{array}$ & Kreteria Perbedaan \\
\hline 1 & Kejahatan & $\begin{array}{l}\text { 1. Perbuatan dilakukan dengan unsur sengaja } \\
\text { 2. Ancaman pidana penjara dan denda } \\
\text { 3. Pelanggaran pasal } 46,47,47 \mathrm{~A}, 48 \text { ayat (1), } \\
\quad 49,50 \text { dan pasal } 50 \mathrm{~A} \text {. }\end{array}$ \\
\hline 2 & Pelanggaran & $\begin{array}{l}\text { 1. Perbuatan dilakukan dengan unsur kealpa- } \\
\text { an dan/atau kelalaian } \\
\text { 2. Ancaman pidana kurungan dan denda } \\
\text { 3. Pelanggaran pasal } 48 \text { ayat (2). }\end{array}$ \\
\hline
\end{tabular}

Sumber Data : Diolah dari Undang- undang Perbankan Nomor 10 Tahun 1998.

Perbedaan antara kejahatan dan pelanggaran pada umumnya dapat dibedakan berdasarkan pembedaan kualitatif dan kuantitatif. Perbedaan kualitatif didasarkan kepada kreteria sikap bathin/unsur subjektif yaitu yang berupa unsur perbuatan kesengajaan dikatagorikan perbuatan kejahatan dan unsur perbuatan kealpaan/ kelalaian dikatagorikan mela-kukan perbuatan pelanggaran. Sedangkan perbedaan dilihat dari segi kuantitatif diukur dari kreteria soal berat dan ringannya ancaman pidana, jika perbuatan tergolong kejahatan diancam pidana penjara dan denda dan untuk perbuatan yang tergolong pelanggaran diancam dengan pidana kurungan dan denda. Penggolongan antara tindak pidana yang berupa kejahatan dengan berupa pelanggaran dicantumkan dalam pasal 51 Undang- undang Perbankan Nomor 10 Tahun 1998.

Pasal 51

(1) Tindak pidana sebagaimana dimaksud dalam pasal 46, 47, pasal 47A, pasal 48 ayat (1), 49, 50 dan pasal 50A adalah kejahatan.

(2) Tindak pidana sebagaimana dimaksud dalam pasal 48 ayat (2) adalah pelanggaran.

Selain dapat diterapkan/ dikenakan ancaman pidana terhadap de-wan komisaris, direksi, pegawai bank dan pihak teralifiasi lainnya, maka dalam Undang- undang 
Perbankan Nomor 7 Tahun 1992 yang diperba-harui dengan Undang- Undang Nomor 10 Tahun 1998 dikenal juga adanya sanksi administratif selain sanksi pidana. Sanksi administratif yang berupa sanksi yang dapat diberikan oleh Bank Indonesia (sekarang Otoritas Jasa Keuangan) dengan berbagai bentuk sanksi administratif seperti terlihat dalam tabel berikut ini ;

Tabel 3

Jenis Sanksi Dalam Undang- undang Perbankan Nomor 10 Tahun 1998

\begin{tabular}{|c|c|c|}
\hline No & $\begin{array}{c}\text { Jenis Sanksi Dalam Undang- } \\
\text { undang Perbankan }\end{array}$ & Kreteria Perbedaan Sanksi \\
\hline 1 & Sanksi pidana & $\begin{array}{l}\text { 1. Pidana penjara minimal } 2 \text { tahun dan } \\
\text { maksimal } 15 \text { tahun } \\
\text { 2. Pidana kurungan minimal } 1 \text { tahun dan } \\
\text { maksimal } 2 \text { tahun } \\
\text { 3. Pidana denda minimal } 4 \text { milyar dan } \\
\text { maksimal } 200 \text { milyar rupiah }\end{array}$ \\
\hline 2 & Sanksi administratif & $\begin{array}{l}\text { 1. Denda uang } \\
\text { 2. Teguran tertulis } \\
\text { 3. Penurunan tingkat kesehatan bank } \\
\text { 4. Larangan untuk turut serta dalam kegiatan } \\
\text { kliring } \\
\text { 5. Pembekuan kegiatan usaha tertentu } \\
\text { 6. Pemberhentian pengurus bank } \\
\text { 7. Pencantuman anggota pengurus, pegawai } \\
\text { bank dan pemegang saham dalam daptar } \\
\text { orang tercela (black list) }\end{array}$ \\
\hline
\end{tabular}

Sumber Data : Diolah dari Undang- undang Perbankan Nomor 10 Tahun 1998.

Apabila ditelaah dari data yang terdapat di dalam tabel di atas, terlihat jenis sanksi yang ada di dalam Undang- undang Perbankan Nomor 10 Tahun 1998, yang dapat dibedakan ke dalam golongan baik sanksi pidana maupun sanksi administratif sebagaimana yang diatur dalam ketentuan pasal 52 Undang- undang Perbankan Nomor 10 Tahun 1998. 
Pasal 52

(1) Dengan tidak mengurangi ketentuan pidana sebagaimana dimaksud dalam pasal 47, pasal 47A, pasal 48, 49 dan pasal 50A, Bank Indonesia dapat menetapkan sanksi administratif kepada bank yang tidak memenuhi kewajibannya sebagaimana dimaksud dalam Undang- undang ini, atau pimpinan Bank Indonesia mencabut izin usaha bank yang bersangkutan.

(2) Sanksi administratif sebagaimana dimaksud dalam ayat (1), antara lain adalah

a. denda uang,

b. teguran tertulis,

c. penurunan tingkat kesehatan bank,

d. larangan untuk turut serta dalam kegiatan kliring,

e. pembekuan kegiatan usaha tertentu, baik untuk kantor cabang tertentu maupun untuk bank secara keseluruhan,

f. pemberhentian pengurus bank dan selanjutnya menunjuk dan mengangkat pengganti sementara sampai Rapat Umum Pemegang Saham mengangkat pengganti yang tetap dengan persetujuan Bank Indonesia, dan

g. pencantuman anggota pengurus, pegawai bank, pemegang saham dalam daptar orang tercela di bidang perbankan.

(3) Pelaksanaan lebih lanjut mengenai sanksi administratif ditetapkan oleh Bank Indonesia.

Dewan komisaris, direksi, pegawai bank dan lainnya, di samping da-pat diterapkan ancaman sanksi pidana sebagaimana diatur dalam keten-tuan pasal 46, 47, 48, 49 dan pasal 50 Undang- undang Perbankan Nomor 10 Tahun 1998, maka Bank Indonesia dapat pula menerapkan sanksi administratif terhadap pihak bank ataupun pihak teralifiasi yang melaku-kan penyimpangan- penyimpangan dalam menjalankan kegiatan opera-sional bank sesuai dengan ketentuan pasal 52 Undang- undang Perbankan Nomor 10 Tahun 1998.

Penerapan sanksi administratif yang dapat diberikan dan/atau dija-tuhkan oleh Bank Indonesia (sekarang Otoritas Jasa Keuangan) kepada bank yang melanggar ketentuan pasal 52 ayat (2) Undang- undang Per-bankan Nomor 7 Tahun 1992 yang diperbaharui dengan Undang- undang Nomor 10 Tahun 1998, dapat berbentuk sanksi administratif berupa denda uang, memberikan teguran secara tertulis, melakukan penurunan tingkat kesehatan 
bank, larangan untuk turut serta dalam kegiatan kliring, pembekuan kegiatan usaha tertentu, baik untuk kantor cabang tertentu maupun untuk bank secara keseluruhan dan pemberhentian pengurus bank (anggota dewan komisaris dan/ atau direksi) dan selanjutnya me-nunjuk dan mengangkat pengganti sementara (anggota dewan komiaris dan/ atau direksi bank) sampai adanya Rapat Umum Pemegang Saham untuk mengangkat pengganti yang tetap dengan persetujuan Bank Indo-nesia, dan pencantuman anggota pengurus, pegawai bank, pemegang saham dalam daptar orang tercela (black list) di bidang perbankan.

Faktor internal yang mempengaruhi perlu dilakukan kebijakan regu-lasi dalam penanggulangan tindak pidana di bidang perbankan, disebab-kan berbagai jenis tindak pidana yang diatur di dalam Undang- undang Perbankan Nomor 10 Tahun 1998, belum sepenuhnya mampu menganti-sipasi kejahatan dan atau tindak pidana di bidang perbankan yang terjadi dalam praktiknya, seperti yang menyangkut, ${ }^{4}$ yaitu ;

(1) Kejahatan yang menyangkut pemberian informasi yang tidak benar dan menyesatkan kepada masyarakat (nasabah),

(2) Kejahatan yang menyangkut praktik bank dalam bank,

(3) Yang menyangkut pelanggaran ketentuan batas maksimum pemberian kredit,

(4) Perbuatan- perbuatan yang mengandung unsur tindak pidana korupsi, dan

(5) Pertanggung jawaban korporasi bank sebagai pelaku kejahatan dalam rangka memberikan perlindungan terhadap nasabah.

Tindakan/perbuatan pejabat atau pegawai bank yang memberian informasi yang tidak benar dan menyesatkan ini, perlu dirumuskan dan/ atau diformulasikan dalam Undangundang perbankan. Sehingga dapat dicegah dan ditanggulangi terjadinya perbuatan/tindakan pejabat atau pegawai bank yang dapat menimbulkan korban dan kerugian bagi ma-syarakat. Bank Indonesia (sekarang Otoritas Jasa Keuangan), perlu secara terus- menerus meningkatkan kegiatan edukasi kepada masyarakat secara terstruktur, terencana dan terkordinasi dengan memberikan pengetahuan dan meningkatkan pemahaman serta prinsif kehati- hatian atas segala risiko tugas dan fungsi bank serta semua layanan produk dan jasa bank.

${ }^{4}$ M. Arief Amrullah, 2002, Politik Hukum Pidana Dalam Perlindungan Korban Kejahatan Ekonomi di Bidang Perbankan, Jurnal Hukum Fak. Hukum UII No. 21 Volume 9 : Jogyakarta, Halaman 17. 
Diharapkan juga tingkat kewaspadaan/kehati- hatian dari masyara-kat jangan cepat terpancing dan percaya begitu saja dengan janji/hadiah, bonus dan bunga yang cukup tinggi yang tidak layak diberikan, tentu ada motif/modus tertentu yang pada akhirnya bermuara pada penyalahgu-naan dengan menggelapkan dana masyarakat, untuk kepentingan kelom-pok atau pribadinya.

Kejahatan yang menyangkut praktik bank dalam bank merupakan usaha bank dalam bank tanpa izin yang berlindung pada usaha bank yang resmi, ${ }^{5}$ yaitu melakukan kegiatan usaha yang dilarang menggunakan dana masyarakat (nasabah) tanpa seizin Bank Indonesia (sekarang Otori-tas Jasa Keuangan). Artinya, dana masyarakat yang disimpan pada bank digunakan untuk tujuan- tujuan tertentu memperkaya diri pribadi atau kelompok/groupnya, diselewengkan baik dananya dipakai untuk berpo-ya- poya keperluan pribadi maupun dalam bentuk pemberian kredit terhadap kelompok/groupnya tanpa kelayakan agunan dan bunga yang seimbang dan tidak diproses secara ketat serta selektip, tanpa memper-hatikan kelayakan usahanya dan tidak mengikuti prosedur pemberian kredit yang ditetapkan bank dalam Standar Operational Procedur (SOP) yang sebenarnya. Pada akhirnya, akibat tidak dilakukan analisis secara benar dan baik, sehingga terjadi pembengkakan kredit macet yang tidak bisa ditutupi di atas kewajaran yang berisiko bank pada akhirnya dapat terkena likuidasi.

Kejahatan praktik bank dalam bank berbeda gradasinya dengan pendirian bank tanpa izin dari pimpinan Bank Indonesia (sekarang Otoritas Jasa Keuangan) sebagaimana yang dituangkan dalam ketentuan pasal 46 ayat (2) Undang- undang perbankan Nomor 7 Tahun 1992 yang diperbaharui dengan Undang- undang Nomor 10 Tahun 1998. Apabila kejahatan praktik bank dalam bank, banknya sudah mendapat izin resmi dari pimpinan Bank Indonesia, tetapi dalam praktik bank itu secara internal menjalankan usaha bank dengan menarik/menggunakan dana masyarakat untuk diselewengkan/disalahgunakan untuk kepentingan memperkaya diri pribadi dan kelompok/groupnnya. Dengan modus memberikan kredit ke kelompok/groupnya bukan disalurkan pada ma-syarakat yang membutuhkan, dan dalam pemberian kredit tidak mengi-kuti ketentuan yang ditetapkan bank, tanpa agunan yang jelas dan bunga yang sebanding.

Praktik bank yang tidak memiliki izin dari pimpinan Bank Indonesia, yaitu sejak dari semula awal memang keberadaan bank itu tidak memiliki izin atau disebut dengan 'bank gelap', dalam menghimpun/menarik dana masyarakat dalam bentuk tabungan, deposito

\footnotetext{
${ }^{5}$ Muhammad Djumhana, Op, Cit, Halaman 463.
} 
dan lainnya. Sehingga kegiatannya yang menjalankan usaha serupa bank dalam bentuk badan hukum tersebut tanpa izin dapat dikenakan ancaman pasal 46 ayat (2) Undangundang Perbankan Nomor 7 Tahun 1992 yang diperbaharui dengan Undang- undang Nomor 10 Tahun 1998. mengingat belum diatur dan dirumuskan kejahatan dalam bentuk praktik bank dalam bank dalam Undang- undang perbankan, sebaiknya perbuatan/tindakan ini menjadi perhatian untuk diformulasikan dalam Undang- undang perbankan. Dengan tujuannya, tiada lain untuk mengurangi terjadinya kejahatan praktik bank dalam bank yang terjadi selama ini, yang dapat menimbul-kan korban pada masyarakat dan kerugian.

Pengertian Batas Maksimum Pemberian Kredit (BMPK) dimaksudkan untuk mengatur portopolio kredit perbankan agar tidak terakumulasi pada satu kelompok atau individual dalam memberikan kredit, sebab konsentrasi kredit pada kelompok atau individu tertentu akan mengan-dung risiko sangat besar bagi bank. ${ }^{6}$ Bank Indonesia menentukan bahwa pemberian kredit kepada nasabah harus dibedakan antara pihak terkait dengan bank dan pihak yang tidak terkait dengan bank. Pihak terkait dengan bank adalah peminjam dan/atau kelompok peminjam yang mempu-nyai keterkaitan dengan bank, seperti dewan komisaris, direksi, pegawai bank beserta keluarganya.

Berdasarkan Peraturan Bank Indonesia Nomor 7/2005 jo Peraturan Bank Indonesia Nomor 8/2005, batas maksimum pemberian kredit ditentukan yaitu :

(a) Pemberian kredit oleh bank kepada pihak terkait dengan bank ditetapkan pa-ling tinggi $10 \%$ dari modal bank,

(b) Pemberian kredit oleh bank kepada yang bukan merupakan pihak terkait dengan bank ditetapkan paling tinggi 20\% dari modal bank, dan

(c) Pemberian kredit oleh bank kepada kelompok peminjam yang bukan meru-pakan pihak terkait dengan bank ditetapkan paling tinggi 25\% dari modal bank.

Bank memberikan kredit pada peminjam yang melebihi batas yang ditetapkan oleh Bank Indonesia, untuk pihak terkait dengan bank di atas 10\% dari modal bank dan bukan pihak terkait dengan bank di atas $20 \%$ dan pada kelompok yang bukan pihak terkait di atas 25\% dari modal bank, berarti bank telah melakukan pelanggaran batas maksimum pemberian kredit. Jika pelanggaran batas maksimum pemberian kredit yang jumlahnya cukup kecil, karena ada unsur kelalaian dapat dikata-gorikan pelanggaran administratif saja.

${ }^{6}$ Batas Maksimum Pemberian Kredit (BMPK), staff.uny.ac.id, Halaman 4. 
Batas maksimum yang diberikan dalam jumlah dana yang lebih besar prosen-tasenya, dilakukan karena ada unsur kesengajaan dengan tidak mengikuti peraturan yang berlaku ditetapkan oleh Bank Indonesia. Per-buatan/tindakan pejabat bank ini dapat dikatagorikan suatu bentuk kejahatan yang membahayakan bank dan sekaligus membahayakan dana masyarakat yang dititipkan padanya, sehingga perlu diatur dan dirumus-kan dalam Undang- undang perbankan.

Perbuatan- perbuatan yang mengandung unsur pidana korupsi, dimaksudkan bahwa dalam tindak pidana perbankan memiliki keter-kaitan dengan unsur- unsur tindak pidana korupsi yang diatur dalam Undang- undang Pemberantasan Tindak Pidana Korupsi Nomor 31 Ta-hun 1999 yang diperbaharui dengan Undang- undang Nomor 20 Tahun 2001 dan sebagaimana yang juga diatur dan dirumuskan dalam ketentuan pasal 49 Undang- undang Perbankan Nomor 7 Tahun 1992 yang diper-baharui dengan Undang- undang Nomor 10 Tahun 1998. Jelasnya, ada dua Undang- undang yang mengatur unsur- unsur tindak pidana korupsi baik di Undang- undang pemberantasan tindak pidana korupsi dan Undangundang perbankan itu sendiri. Agar tidak timbul kerancuan dalam implementasinya sebaiknya ketentuan ini ditegaskan dalam Undang- undang perbankan, dan dengan menerapkan Undang- undang perbankan dan bukan undang- undang pemberantasan tindak pidana korupsi yang selama ini banyak menjerat pejabat bank yang melakukan tindak pidana korupsi.

Penerapan azas kekhususan sistematis dalam pasal 14 Undang- undang Pemberantasan Tindak Pidana Korupsi Nomor 31 Tahun 1999 yang diperbaharui dengan Undang- undang Nomor 20 Tahun 2001, yang merupakan pengembangan dari azas lex spesialis derogate legi generali yang terdapat di dalam pasal 63 ayat (2) KUHP, di mana diberlakukan penerapan Undang- undang yang "lebih khusus dari yang khusus" dalam proses penegakan hukum dan dengan tidak dicantumkan azas kekhu-susan sistematik hukum pidana administrasi dalam Undang- undang Perbankan Nomor 7 Tahun 1992 yang diperbaharui dengan Undang- undang Nomor 10 Tahun 1998, sehingga rumusan yang termuat di dalam Undang- undang perbankan menjadi wilayah abu- abu (gray area) dan dapat menimbulkan multi interprestasi.

Melihat azas kekhususan sistematis ini belum lengkap karena hanya ada pada Undang- undang tindak pidana korupsi, sementara dalam Undang- undang pidana administrasi yang mempunyai sanksi pidana di bidang perbankan, tidak ada penjelasan secara spesifik. Sebaiknya, harus adanya penormaan azas kekhususan sistematis di dalam 
Undang- undang pidana administrasi di bidang perbankan. Perlunya diformulasikan dan atau dirumuskan penormaan secara eksplisit azas kekhususan sistematis ke dalam Undang- undang pidana administrasi di bidang perbankan. Ditujukan untuk mengatasi terjadinya kriminalisasi kebijakan yang dise-babkan adanya perdebatan panjang antara hukum pidana korupsi dan hukum pidana admi-nistrasi di bidang perbankan. Ada limitasi yang jelas antara pidana administrasi di bidang perbankan dan pidana korupsi, yang tujuannya agar bisa tercapai pembentukan hukum dan upaya penegakan hukum yang efisien dan epektif di bidang perbankan.

Permasalahan lain dari substansi/materi yang termuat di dalam Undang- undang Perbankan Nomor 7 Tahun 1992 yang diperbaharui dengan Undang- undang Nomor 10 Tahun 1998, adalah belum diaturnya secara rinci dan terstruktur persoalan perlindungan terhadap nasabah bank. Padahal persoalan perlindungan terhadap nasabah yang menjadi korban tindak pidana perbankan kian menjadi penting dan perlu untuk diperhatikan, mengingat kerugian dan akibat yang ditimbulkan cukup besar, sehingga pengaturan perlindungan korban (nasabah bank) perlu diakomodir di dalam Undang- undang perbankan.

Persoalan perlindungan terhadap nasabah dalam sistem perbankan di Indonesia masih belum terlembaga dengan baik, sehingga penegakan dan penerapan hukum pidananya kian menjadi lemah dan belum optimal. Padahal sudah ada pengaturan perlindungan terhadap saksi dan korban dalam Undang- undang Nomor 13 Tahun 2006, yang dalam pasal 1 ayat (2) nya disebutkan 'korban adalah seseorang yang mengalami penderitaan phisik, mental dan/atau kerugian ekonomi'. Dengan demiki-an, perlin-dungan korban diakomodir dan diakui yang berkaitan dengan kerugian ekonomi termasuk korban tindak pidana di bidang perbankan dalam Undang- undang tersebut.

Begitu juga di dalam ketentuan pasal 7 hurup f Undang- undang Perlindungan Konsumen Nomor 8 Tahun 1999, yang memberikan 'kom-pensasi, ganti kerugian dan/atau penggantian atas kerugian akibat penggunaan, pemakaian dan pemanfaatan barang dan/atau jasa yang diperdagangkan'. Artinya, terhadap konsumen (nasabah bank) yang menderita kerugian akibat perbuatan yang dilakukan secara tidak ber-tanggung jawab dan melawan hukum, berhak atas kompensasi dan atau ganti kerugian. Walaupun sudah ada ketentuan Undang- undang Perlin-dungan Konsumen Nomor 8 Tahun 1999, tetapi dalam 
beberapa kasus konsumen (nasabah bank) yang menjadi korban tindak pidana perbankan tidak mendapat perlindungan hukum secara optimal. ${ }^{7}$

Di dalam Undang- undang perbankan belum ada pengaturannya secara integratif dan komprehensif, sehingga di dalam substansi/materi Undang- undang perbankan perlu dirumuskan dan diformulasikan ketentuan tentang perlindungan terhadap korban (nasabah bank) secara jelas dan terperinci dengan mengkriminalisasikan, mulai dari rumusan perbuatan/tindak pidana, pertanggung jawaban pidana beserta pidana dan pemidanaan. Terhadap korporasi dapat dijerat dan dijadikan sebagai subjek dan pelaku tindak pidana perbankan. Dengan ditetapkan korporasi dapat dijadikan sebagai subjek dan pelaku kejahatan/tindak pidana perbankan, sehingga dapat memberikan perlindungan terhadap nasabah yang menjadi korban bukan hanya terhadap calon korban (potential victim) melainkan juga perlindungan terhadap korban secara langsung (actual victim), sehingga akan menciptakan keseimbangan dalam hukum pidana antara pelaku dengan korban dan antara calon korban dengan korban secara langsung. Pengenaan sanksi pidana denda yang cukup tinggi terhadap korporasi (bank) dengan kombinasi alternatip sanksi pidana lainnya, seperti publicity sanction. ${ }^{8}$

Kelemahan lain dari substansi/materi yang termuat dalam Undang- undang perbankan,tidak diatur mengenai beban tanggungjawab bagi sipembuat/pelaku percobaan, pembantuan dan pembuat/pelaku permu-fakatan jahat untuk melakukan tindak pidana perbankan, padahal kata-gori yang disebutkan dimaksud diatur dalam pasal 15 Undangundang pemberantasan tindak pidana korupsi. Termasuk juga perbuatan menyalahgunakan kewenangan karena jabatan atau kedudukan, menyalah-gunakan sarana karena jabatan atau kedudukan, subjek tindak pidana diperluas, sanksi pidana baik pidana pokok maupun pidana tambahan diatur sedemikian rupa. ${ }^{9}$ Hal ini dilakukan untuk mengantisipasi dalam upaya penanggulangan tindak pidana perbankan yang perkembangannya semakin kompleks ke depannya.

Ditelusuri dan ditelaah dari substansi Undang- undang Perbankan Nomor 7 Tahun 1992 yang diperbaharui dengan Undang- undang nomor 10 Tahun 1998, dalam hal masalah jenis dan perumusan sanksi pidana/ sanksi administratif, hanya mencantumkan pidana pokok berupa penja-ra/kurungan dan denda yang dirumuskan secara kumulatif.

${ }^{7}$ Yusuf Shofie, 2009, Perlindungan Konsumen dan Instrument- instrument Hukumnya, PT. Citra Aditya Bakti : Bandung, Halaman 81.

${ }^{8} \mathrm{M}$. Arief Amrullah, op, Cit, Halaman 21.

${ }^{9}$ Hartiwiningsih, $O p$, Cit, Halaman 25. 
Jelasnya, ti-dak ada pidana tambahan atau jenis sanksi tindakan yang diintegra-sikan ke dalam sistem pemidanaan.

Perumusan pidana pokok dan denda secara kumulatif, mengandung kelemahan dan dikhawatirkan tidak epektif, ${ }^{10}$ yang disebabkan ;

1. Perumusan sanksi pidana yang bersifat kumulatif yang imperatif sehingga sangat kaku untuk diterapkan, mengingat hakim tidak diberi kesempatan untuk memilih sanksi pidana yang dijatuhkan,

2. Kumulasi pidana penjara dan denda sulit diterapkan untuk korporasi, dan

3. Dengan dikumulasikannya pidana denda yang tinggi (minimal satu milyar rupiah dan maksimal dua ratus milyar rupiah) dengan pidana penjara/kurungan, dikhawatirkan denda tidak akan diba-yar karena dalam Undang- undang perbankan tidak ada ketentuan khusus yang menyimpang dari pasal 30 KUHP (apabila tidak di-bayar, hanya dikenakan pidana kurungan pengganti 6 bulan atau maksimal 8 bulan apabila ada pemberatan).

Dalam upaya mengantisipasi kelemahan perumusan pidana pokok dan denda secara kumulasi, sebaiknya dibuat kebijakan formulasi dalam Undang- undang perbankan, ${ }^{11}$ sebagai berikut ;

a. Menggunakan perumusan kumulatif alternatif,

b. Dibuat aturan khusus yang menyimpang dari pasal 30 KUHP dengan mengacu perumusan seperti pasal 16 Undang- undang Nomor 31 Tahun 1999 (mengenai pelaksanaan uang pengganti) atau seperti pasal 76 konsep RUU KUHP Tahun 2000, yaitu jika denda tidak dibayar, harta bendanya disita dan dilelang untuk membayar denda itu atau diambil dari pendapatan terpidana dan tidak tidak ada (tidak cukup), dikenakan pidana penjara dan/atau kurungan pengganti yang lamanya tidak melebihi maksimum pidana penjara dan/atau kurungan yang diancamkan, dan

c. Dibuat aturan khusus yang menyimpang dari pasal 30 KUHP untuk denda yang tidak dibayar oleh korporasi, aturan seperti sub b di atas, tetapi dengan pidana pengganti yang sesuai untuk korpo-rasi (misalnya pencabutan izin usaha, pembekuan kegiatan usaha-nya ataupun pembubaran korporasi yang diikuti dengan likuidasi.

\footnotetext{
${ }^{10}$ Barda Nawawi Arief, $O p$, Cit, Halaman 154.

${ }^{11} \mathrm{Ibid}$, Halaman 155.
} 
Berbagai kelemahan dan atau kekurangan secara internal yang ter-muat di dalam Undang- undang Perbankan Nomor 10 Tahun 1998 yang mengatur tindak pidana perbankan seperti yang diutarakan di atas, se-hingga terhadap Undang- undang Perbankan dimaksud perlu dilakukan penyempurnaan, revisi dan atau perbaikan dengan melakukan kebijakan regulasi secara cepat dan tepat, untuk mengantisipasi berbagai jenis dan modus tindak pidana di bidang perbankan yang berkembang begitu cepat di era digitalisasi dan globalisasi saat ini.

\section{Faktor Ekternal Yang Mempengaruhi Perlu Dilakukan Kebijakan Regulasi Dalam Penanggulangan Tindak Pidana di Bidang Perban-kan}

Tindak pidana di bidang perbankan yang diatur regulasinya dalam Undang- undang Perbankan Nomor 10 Tahun 1998, belum sepenuhnya dapat mengantisipasi perkembangan tindak pidana/kejahatan perbankan yang terjadi. Faktor ekternal yang mempengaruhi perlu dilakukan kebi-jakan regulasi dalam penanggulangan tindak pidana di bidang perban-kan, mengingat di dalam Undang- undang Perbankan Nomor 10 Tahun 1998 masih terdapat berbagai kekurangan dan atau kelemahan, sehingga Pemerintah mengambil langkah kebijakan. Langkah kebijakan yang di-tempuh dan dilakukan yang berhubungan dengan kegiatan operasional perbankan diatur pula dan tersebar di berbagai peraturan perundangundangan lainnya yang berlaku yang berkaitan dengan tindak pidana di bidang perbankan, seperti terlihat dalam tabel berikut ini ;

Tabel 4

Tindak Pidana Yang Berkaitan Dengan Kegiatan Perbankan di Luar Undang- undang Perbankan Nomor 10 Tahun 1998

\begin{tabular}{|l|l|l|}
\hline No & \multicolumn{1}{|c|}{$\begin{array}{c}\text { Tindak Pidana Yang Berkaitan } \\
\text { Dengan kegiatan Perbankan }\end{array}$} & \multicolumn{1}{c|}{ Pasal } \\
\hline 1 & $\begin{array}{l}\text { Kitab Undang- undang Hukum Pidana (KUHP) } \\
\text { Nomor 1 Tahun 1946 }\end{array}$ & $\begin{array}{l}\text { Pasal 263, 264, 362, 363, } \\
372,374 \text { dan pasal 378. }\end{array}$ \\
\hline 2 & $\begin{array}{l}\text { Undang- undang Pemberantasan Tindak Pidana } \\
\text { Korupsi Nomor 31 Tahun 1999 yang diperbaha- } \\
\text { rui dengan Undang- undang Nomor 20 Tahun } \\
\text { 2001 }\end{array}$ & $\begin{array}{l}\text { Pasal 2 dan pasal 3, pasal 4, } \\
\text { pasal 5, pasal 18 ayat (1). }\end{array}$ \\
\hline 3 & Undang- undang Penanaman Modal Nomor 8 & Pasal 103 ayat (1) \\
\hline
\end{tabular}




\begin{tabular}{|l|l|l|}
\hline & Tahun 1995 & \\
\hline 4 & $\begin{array}{l}\text { Undang- undang Pencegahan dan Pemberanta- } \\
\text { san Tindak Pidana Pencucian Uang Nomor 25 } \\
\text { Tahun 2003 yang diperbaharui dengan Undang- } \\
\text { undang Nomor 8 Tahun 2010 }\end{array}$ & Pasal 3, 4 dan pasal 5. \\
\hline 5 & $\begin{array}{l}\text { Undang- undang Informasi dan Transaksi Elek- } \\
\text { tronik Nomor 11 Tahun 2008 }\end{array}$ & $\begin{array}{l}\text { Pasal 46 ayat (1) dan (3), } \\
\text { pasal 48 ayat (2), dan pasal } \\
51 \text { ayat (2). }\end{array}$ \\
\hline 6 & $\begin{array}{l}\text { Undang- undang Transper Dana Nomor 3 Tahun } \\
\text { 2011 }\end{array}$ & $\begin{array}{l}\text { Pasal 79, 81, 83 dan pasal } \\
84 .\end{array}$ \\
\hline
\end{tabular}

Sumber Data : Diolah Dari Berbagai Undang- undang Yang Berkaitan Dengan Kegiatan Perbankan.

Ditelaah data yang tertuang dalam tabel di atas, terlihat secara jelas faktor ekternal yang mempengaruhi perlunya dilakukan kebijakan regulasi dalam penanggulangan tindak pidana di bidang perbankan, maka terhadap beberapa tindak pidana yang terkait dengan kegiatan operasional perbankan yang berada dan terdapat di luar Undang- undang Perbankan Nomor 10 Tahun 1998, yaitu yang terdapat dan termuat di da-lam Kitab Undang- undang Hukum Pidana (KUHP) Nomor 1 Tahun 1946 dan Undang- undang Pemberantasan Tindak Pidana Korupsi Nomor 31 Tahun 1999 yang diperbaharui dengan Undang- undang Nomor 20 Tahun 2001.

Peraturan perundang- undangan lainnya yang berkaitan dengan tindak pidana di bidang perbankan, diatur pula ketentuannya di dalam Undang- undang Pasar Modal Nomor 8 Tahun 1995, Undang- Undang- undang Pencegahan dan Pemberantasan Tindak Pidana Pencucian Uang Nomor 25 Tahun 2003 yang diperbaharui dengan Undang- undang Nomor 8 Tahun 2010, Undang- undang Informasi dan Transaksi Elektronik Nomor 11 Tahun 2008 dan termasuk pula Undang- undang Transper Dana Nomor 3 Tahun 2011.

Kitab Undang- undang Hukum Pidana (KUHP) merupakan sebuah produk hukum yang mengatur secara tegas dan menyeluruh terhadap semua kejahatan atau tindak pidana pada umumnya. Dengan demikian, KUHP dapat dijadikan rujukan dan dapat dipergunakan serta diterapkan dalam menanggulangi tindak pidana yang berkaitan dengan kegiatan operasional perbankan. Apalagi dalam menghadapi era globalisasi dengan tingkat penggunaan informasi tehnologi yang cukup canggih ber-kembangnya begitu cepat dalam 
penggunaan transaksi bisnis perbankan, tentu dapat dipahami apabila di dalam rumusan pasal- pasal yang termuat di dalam Undang- undang Perbankan Nomor 10 Tahun 1998 belum dapat sepenuhnya mengantisipasi dan mengaturnya.

Untuk itu, ada beberapa pasal yang termuat di dalam KUHP, dapat dijadikan acuan dan diterapkan dalam penanggulangan tindak pidana di bidang perbankan. Adapun pasal- pasal dimaksud di dalam KUHP yang berkaitan erat dalam penanggulangan tindak pidana di bidang perbankan yang dapat diterapkan yaitu pasal 263, 264, 362, 363, 372, 374 dan pasal 378 KUHP.

Ketentuan yang termuat di dalam pasal 263 dan pasal 264 KUHP di atas, termasuk dalam katagori tindak pidana pemalsuan. Ketentuan pasal 263 KUHP mengatur tindak pidana pemalsuan surat pada umumnya da-lam bentuk pokok dan yang termuat dalam pasal 264 KUHP mengatur tindak pidana pemalsuan surat dalam bentuk khusus yang diperberat. Pasal 263 dan pasal 264 KUHP dapat diterapkan terhadap pelaku tindak pidana yang berkaitan dengan kegiatan operasional bank dalam hal terjadinya tindak pidana pemalsuan surat/warkat- warkat atau dokumen- dokumen bank. Di dalam melakukan pemalsuan surat/ warkat- warkat atau dokumen- dokumen bank berkolerasi dengan dipenuhi unsur peni-puannya, dengan modus operandinya bervariasi, memalsukan dokumen (sertifikat tanah) yang dipergunakan sebagai jaminan kredit, mark up nilai transaksi jaminan/agunan yang tidak sesuai dengan kondisi phisik yang sebenarnya, mendapatkan kredit dengan jaminan/agunan piktif dan mendapatkan jaminan dengan proyek piktif.

Tindak pidana pemalsuan lainnya, dapat berupa memanipulasi transaksi surat- surat berharga berupa sertifikat deposito, obligasi, promes dan lainnya, memanipulasi transaksi dokumen dalam bentuk leter of credit (L/C), pemalsuan cek, bilyet giro, pemalsuan kartu ATM, kartu kredit dan lain sebagainya. Apabila hal yang demikian terjadi terhadap pelaku tindak pemalsuan surat/warkat- warkat dan dokumen- dukumen bank dapat dikenakan ancaman yang tertuang di dalam ketentuan pasal 263 pidana penjara maksimal selama 6 tahun dan apabila melanggar pasal 264 KUHP, pidana penjara maksimal 8 tahun.

Pasal 362 dan pasal 363 angka 4e dan 5e KUHP bukan hanya dapat diterapkan dan menjerat pelaku tindak pidana pencurian pada umumnya. Namun demikian, dapat juga diterapkan terhadap pelaku tindak pidana di bidang perbankan. Dengan modus operandinya, dalam pembobolan ATM melalui skimmer meletakan sesuatu alat tertentu yang bisa merekam kartu ATM, dengan cara mengkopy data kartu ATM asli nasabah 
termasuk PIN nya, tidak lebih dalam beberapa menit praktik yang terjadi atas bobolnya rekening nasabah yang dicuri lewat ATM.

Pasal 372 dan 374 KUHP termasuk dalam golongan tindak pidana penggelapan yang sering terjadi dalam tataran praktiknya dalam ke-giatan operasional perbankan. Benda atau uang yang mau dikuasai/ diambil sudah berada dalam kekuasaanya akibat hubungan kerja (orang yang bekerja di lembaga perbankan) dengan kepiawaian karyawan bank simpanan nasabah dalam rekening tabungan dapat ditata sedemikian rupa canggihnya melalui komputerisasi, sehingga orang yang memiliki keahlian di bidang tehnologi mudah untuk memanipulasi uang yang ada dalam rekening tabungan, dengan cara mengambil atau mengurasnya uang tersebut untuk kepentingan diri pribadinya. Tindak pidana penggelapan tidak dapat dilakukan oleh orang luar bank, karena tidak mempu-nyai akses untuk itu, akan tetapi dapat dilakukan oleh orang dalam bank (pegawai dan pejabat bank) yang mempunyai kepentingan karena sudah berada dalam kekuasaanya benda atau uang yang mau dikuasai atau diambil tersebut.

Sedangkan pasal 378 KUHP yang berkaitan adanya unsur penipuan dapat saja terjadi, mengingat beragamnya usaha dan produk serta ke-giatan jasa- jasa yang ditawarkan perbankan kepada masyarakat (nasa-bah). Tanpa disadari, terkadang ada unsur penipuan yang terjadi dalam kebijakan pemberian kredit, yaitu pemberian kredit piktif yang dilakukan orang dalam bank (pejabat dan karyawan bank) bekerja sama dengan orang dalam bank yang lainnya dengan merekayasa atau memanipulasi sedemikian rupa data nasabah, seolah- olah ada nasabah padahal hanya nasabah rekayasa hanya sekedar untuk menarik atau mengambil uang pinjaman bagi keperluan pribadinya. Apabila hal yang demikian terjadi dan memenuhi unsur- unsur ketentuan pasal 378 KUHP, pelaku (orang dalam bank) dapat dikenakan ancaman maksimal selama 4 tahun.

Dalam kegiatan menjalankan usaha bank, dapat pula terjadinya ko-rupsi. Korupsi adalah apabila seorang pegawai/karyawan bank mene-rima pemberian yang disodorkan oleh seorang dengan maksud mem-pengaruhinya agar memberikan perhatian istimewa pada kepentingan si pemberi. Kadang- kadang juga berupa perbuatan menawarkan pemberian uang hadiah lain yang dapat menggoda. Termasuk dalam pengertian ini juga pemerasan yakni permintaan pemberian atau hadiah seperti itu dalam dalam pelaksanaan tugas- tugas publik. ${ }^{12}$

\footnotetext{
${ }^{12}$ Syed Hussein Alatas, 2003, Prilaku Korupsi, Ghalia Indonesia : Jakarta, Halaman 64.
} 
Salah satu upaya untuk mempersempit ruang gerak dan upaya pencegahan dan pemberantasan tindak pidana korupsi, pemerintah terus memperbaharui substansi/ materi peraturan perundang- undangan yang mengatur tindak pidana korupsi, mulai dari Undangundang Nomor 24 (PRP) Tahun 1960, Undang- undang Nomor 3 Tahun 1971, Undangundang Nomor 31 Tahun 1999 hingga sampai pada Undang- undang Nomor 20 Tahun 2001. Substansi/materi tindak pidana korupsi unsur- unsurnya termuat di dalam ketentuan pasal 2 dan pasal 3 Undang- undang tentang Pemberantasan Tindak Pidana Korupsi Nomor 31 Tahun 1999 yang diperbaharui dengan Undang- undang Nomor 20 Tahun 2001.

Ketentuan pasal 2 dan pasal 3 Undang- undang Pemberantasan Tindak Pidana Korupsi Nomor 20 Tahun 2001 dapat menjerat dan diber-lakukan terhadap pelaku tindak pidana korupsi yang dilakukan di ling-kungan perbankan, sepanjang memenuhi unsur- unsur tindak pidana korupsi dimaksud. Pelaku tindak pidana korupsi yang berkaitan dengan kegiatan operasional perbankan, dapat dilakukan oleh pemegang saham, dewan komisaris, direksi, pejabat dan pegawai bank dan termasuk pihak teralifiasi lainnya, seperti dalam kasus pelanggaran terhadap batas Mak-simum Pemberian Kredit (BMPK), pelanggaran terhadap Bantuan Likuidi-tas Bank Indonesia (BLBI) dan kasus- kasus dalam hal pejabat bank peme-rintah yang meminta atau menerima imbalan, suap atau hadiah dalam kebijakan mempermudah tanpa melalui analisis mendalam dalam pem-berian kredit bagi nasabah, termasuk di lingkungan bank- bank swasta, juga dapat dijerat Undang- undang Pemberantasan Tindak Pidana Korup-si, mengingat juga dalam bank- bank swasta menyangkut adanya dana pihak ketiga (masyarakat) yang ditempatkan di perbankan swasta terse-but, jika terpenuhi adanya unsur gratifikasi, suap dalam pemberian kredit, dalam kasus penyalahgunaan uang BLBI yang dikucurkan oleh Bank Indonesia dan lain sebagainya.

Kasus- kasus korupsi lainnya di lingkungan perbankan dapat terjadi dalam berbagai bentuk, ${ }^{13}$ yaitu permainan dalam penilaian atau analisis yang lemah terhadap prinsif $5 \mathrm{C}$ (karakter,kemampuan, modal, jaminan dan kondisi ekonomi usaha) yang menjadi prinsif dalam pemberian kredit, terjadinya mark up (pengelem-bungan) terhadap proyek- proyek yang akan dibiayai dengan kredit bank, pemberian kredit yang diutama-kan pada proyek/usaha- usaha yang berada pada satu grup dengan bank itu sendiri, adanya uang hangus/komisi yang berakibat berkurangnya jumlah uang kredit yang diterima oleh nasabah dan menjadi tingginya bunga epektif dibandingkan dengan bunga resminya dan

\footnotetext{
${ }^{13}$ Moeljatno, Et, al, 1989, Ekonomi Korupsi, PT. Pustaka Quantum : Jakarta,Halaman 101.
} 
penggunaan kredit yang ternyata tidak sesuai dengan ketentuan yang tercantum dalam bunga pinjaman.

Pasar modal mempunyai peranan penting dalam mobilisasi dana untuk menunjang pembangunan nasional. Pasar modal diatur dengan Undang- undang Nomor 8 Tahun 1985. Ketentuan pidana dalam Undang- undang Pasar Modal diatur pada Bab XV mulai dari ketentuan pasal 103 hingga pasal 110. Dalam ketentuan pasal 110 Undang- undang Pasar Modal Nomor 8 Tahun 1995, dapat dibedakan klasifikasi tindak pidana, yaitu ;

1. Tindak pidana pasar modal yang berupa kejahatan diatur dalam ketentuan pasal 103 ayat (1), pasal 104, pasal 106 dan pasal 107, dan

2. Tindak pidana pasar modal yang berupa pelanggaran diatur dalam ketentuan pasal 103 ayat (2), pasal 105 dan pasal 109.

Keterkaitan dan hubungan tindak pidana di bidang perbankan dengan kegiatan pasar modal, tercermin dari peranan bank dalam menunjang kegiatan pasar modal yaitu ;

a. Bank sebagai kustodian, yaitu sebagai pihak yang memberikan jasa penitipan efek dan harta lain yang berkaitan dengan efek serta jasa lainnya, termasuk menerima deviden, bunga dan hak- hak lain, menyelesaikan transaksi efek dan mewakili pemegang rekening yang menjadi nasabahnya, dan

b. Bank sebagai wali amanat, yaitu sebagai pihak yang mewakili kepentingan pemegang efek yang bersifat utang.

Dari peranan bank sebagai kustodian dan sebagai wali amanat dalam menunjang kegiatan pasar modal dapat menjadikan bank sebagai subjek hukum dari tindak pidana pasar modal. Sebagai subjek hukum bank dapat dikenakan ancaman pidana dalam Undangundang Pasar Modal, yaitu apabila bank menyelenggarakan kegiatan usaha sebagai kustodian dan wali amanat tanpa persetujuan dan terdaptar di Bapepam dengan melanggar pasal 43 dan pasal 50 Undang- undang Pasar Modal Nomor 8 Tahun 1985. Apabila lembaga perbankan sebagai kustodian tidak memili-ki persetujuan/izin tertulis dari Bapepam, maka lembaga perbankan sebagai subjek hukum dapat dikenakan ancaman pidana sebagaimana yang tertuang dalam pasal 103 ayat (1) Undang- undang Pasar modal Nomor 8 Tahun 1985, dengan ancaman pidana penjara paling lama 5 tahun dan denda paling banyak lima milyar rupiah.

Begitu juga lembaga perbankan sebagai wali amanat, yaitu sebagai pihak yang mewakili kepentingan pemegang efek yang bersifat utang harus terdaptar di Badan Penanaman Pasar Modal (Bapepam) sebagai-mana yang dimaksudkan tertuang di dalam 
ketentuan pasal 50 ayat (2) Undang- Undang Pasar Modal Nomor 8 Tahun 1985. Jika tidak terdaptar di Bapepam lembaga perbankan yang menjalankan fungsi sebagai wali amanat dapat dijerat atau dikenakan dengan ancaman pidana penjara maksimal 5 tahun dan denda maksimal sebesar lima milyar rupiah sesuai dengan rumusan yang termuat di dalam pasal 103 ayat (1) Undang- undang Pasar Modal Nomor 8 Tahun 1985.

Lembaga perbankan dapat pula dijadikan sebagai sarana untuk me-nyembunyikan dan atau mengaburkan asal usul uang yang berasal dari berbagai bentuk kejahatan, baik hasil kejahatan korupsi, narkotika, perju-dian, penyelundupan, perdagangan manusia (trafikking) dan lainnya, se-hingga uang yang disembunyikan dan atau dikaburkan itu dapat digunakan seolah- olah sebagai uang yang sah (legal) tanpa terdeteksi uang dimaksud yang berasal dari kejahatan. Tindakan untuk menyembunyi-kan dan atau mengaburkan asal usul uang hasil kejahatan inilah yang dikenal dengan pencucian uang (money loundering). Pengaturan tindak pidana pencucian uang yang berkaitan dengan lembaga perbankan, diatur di dalam ketentuan pasal 3, pasal 4 dan pasal 5 Undang- Undang Pen-cegahan dan Pemberatasan Tindak Pidana Pencucian Uang Nomor 25 Tahun 2003 yang diperbaharui dengan Undang- Undang Nomor 8 Tahun 2010.

Dari pasal 3, pasal 4 dan pasal 5 Undang- undang Pencegahan dan Pemberatasan Tindak Pidana pencucian Uang Nomor 8 Tahun 2010 di atas, secara jelas terlihat arti dari tindak pidana pencucian uang yang diru-muskan Undang- undang merupakapn suatu bentuk kejahatan yang dilakukan oleh seseorang dan/ atau korporasi dengan sengaja menempat-kan, mentransper, mengalihkan, membelanjakan, membayarkan, menghibahkan, menitipkan, membawa ke luar negeri, mengubah bentuk, menu-karkan dengan mata uang atau surat berharga atau perbuatan lain atas harta kekayaan yang diketahuinya atau patut diduganya merupakan hasil tindak pidana. Dengan tujuan menyembunyikan atau menyamarkan asal usul harta kekayaan itu, termasuk juga yang menerima dan menguasainya.

Modus oprandi lainnya dapat digunakan sistem pengiriman uang melalui Real Time Gross Settlement (RTGS), maka dalam hitungan detik pelaku kejahatan dengan mudah memindahkan uang dari hasil kejahatan yang dilakukan. Penggunaan media pembayaran yang bersifat elektronik (electronic funds trasfer) akan lebih menyulitkan dalam pelacakan 
diikuti pula dengan uang tersebut masuk ke dalam sistem perbankan di negara yang ketat dalam menerapkan ketentuan rahasia bank. ${ }^{14}$

Dalam rangka bank untuk mempersempit ruang gerak terjadinya tindak pidana pencucian uang, dikeluarkanlah Peraturan bank Indonesia Nomor 3/10/PBI/2001, tentang 'Penerapan Prinsif Mengenal Nasabah' atau yang terkenal dengan sebutan know your costomer principles sebagai salah satu upaya untuk mencegah agar sistem perbankan tidak digunakan sebagai sarana kejahatan pencucian uang, baik yang dilakukan secara langsung maupun tidak langsung oleh pelaku kejahatan. Dalam Peraturan bank Indonesia tersebut, lembaga perbankan diwajibkan untuk menerap-kan prinsif mengenal nasabah, yang terdiri dari kebijakan dan prosedur penerimaan dan identifikasi nasabah, pemantauan rekening nasabah, pemantauan traksaksi nasabah serta kebijakan dan prosedur manajemen risiko.

Penerapan kebijakan dan prosedur tersebut bertujuan agar lembaga perbankan dapat mengenali propil nasabah maupun karakteristik setiap transaksi nasabah, sehingga pada gilirannya lembaga perbankan dapat mengidentifikasi transaksi keuangan yang mencurigakan (suspicious transaction) dan selanjutnya melaporkan kepada Pusat Pelaporan dan Analisis Transaksi Keuangan (PPATK). Dengan menerapkan prinsif mengenal nasabah berarti bank juga dapat meminimalkan kemungkinan risiko yang mungkin timbul, yaitu operational risk (risiko operasional) legal risk (risiko hukum) dan reputational risk (risiko reputasi).

Kemajuan tehnologi dan informasi tentu mempunyai dampak positip dan negatip, dampak positif mudahnya memperoleh informasi kapanpun dan dimanapun, termasuk salah satunya dapat memudahkan dalam melakukan transaksi bisnis perbankan. Sedangkan dampak negatipnya, terhadap kegiatan operasional perbankan antara lain membuka ruang terjadinya perusakan alat untuk memasukkan kartu ATM yang diganti dengan skimmer (alat merekam data) yang tengah terjadi di mesin- mesin ATM.

Terhadap pelaku yang diduga telah melakukan pembobolan uang nasabah melalui kartu ATM ataupun melakukan perusakan alat untuk memasukkan kartu ATM yang diganti dengan skimmer yang tengah terjadi di mesin- mesin ATM dan terjadi pembobolan uang nasabah, terhadap pelakunya dapat dikenakan ketentuan pasal 30 ayat (1) Un-dangundang Informasi dan Transaksi Elektronik Nomor 11 Tahun 2008 dikenakan ancaman pidana sebagaimana yang diatur dalam dalam pasal 46 ayat (1) dengan pidana penjara maksimal 6 tahun dan denda maksimal enam ratus juta rupiah.

\footnotetext{
${ }^{14}$ Ibid, Halaman 15.
} 
Merupakan kewajiban bagi bank untuk menjaga dan menye-lenggarakan keamanan dan ketertiban bagi nasabah yang menggunakan kartu ATM untuk bertransaksi mengambil uangnya di mesin- mesin ATM. Pembobolan uang nasabah melalui mesin- mesin ATM karena kekurang hati- hatian dan karena kelalaian nasabah itu sendiri, maka perbankan tidak dapat diminta pertanggung jawaban dan kewajiban mengganti kerugian yang menimpa nasabah.

Dalam tataran praktik penyidik jarang sekali menggunakan pasal 30 ayat (1) dan (3), pasal 32 ayat (2) dan pasal 36 Undang- undang Informasi dan Transaksi Elektronik. Boleh dikatakan, penyidik apabila terjadi tindak pidana pembobolan uang nasabah melalui mesinmesin ATM lebih banyak menjerat pelaku dengan menggunakan pasal 263 KUHP yang mengatur tindak pidana pemalsuan kartu ATM dan pasal 362 KUHP dalam bentuk tindak pidana pencurian dengan cara mengambil uang milik orang lain (nasabah) dengan cara melawan hukum.

Transper dana merupakan salah satu bagian dari kegiatan opera-sional bank, yang manfaatnya sangat dirasakan langsung oleh masyarakat (nasabah) pengguna untuk mempercepat dan memperlancar arus perpu-taran dan peredaran lalu lintas giral. Dengan meningkatnya jumlah tran-saksi transper dana maupun nilai nominal transaksi serta jenis media yang digunakan, terkadang dapat menimbulkan permasalahan yang terjadi di dalam tataran praktiknya. Untuk itu, demi menjaga dan atau menjamin keamanan dan kelancaran transaksi transper dana serta dalam rangka memberikan kepastian bagi para pihak yang terkait dalam penye-lenggaraan kegiatan transper dana, sehingga perlu dilakukan pengaturannya melalui pembentukan peraturan perundang- undangan transper dana dengan Undang- undang Transper dana Nomor 3 Tahun 2011.

Menyangkut kegiatan transper dana merupakan salah satu bagian dari kegiatan operasional bank, maka jika ada penyimpangan dan atau pelanggaran yang dilakukan terhadap kegiatan transper dana, pelakunya dapat dikenakan dan dijerat ancaman pidana sebagaimana yang diatur dalam rumusan pasal 79, pasal 81, pasal 82, pasal 83 dan pasal 84 Un-dang- undang Transper dana Nomor 3 Tahun 2011.

Apabila diperhatikan dari rumusan pasal 79, pasal 81, pasal 83 dan pasal 84 Undangundang Transper Dana Nomor 3 Tahun 2011 di atas, unsur- unsur dari tindak pidana yang berkaitan dengan kegiatan transper dana yang diselenggarakan oleh perbankan, yaitu unsur subjektif yaitu meliputi setiap orang yang bisa dilakukan manusia orang perorangan dan badan hukum (korporasi). Manusia orang perorangan bisa orang luar dan bisa orang 
dalam perbankan itu sendiri, yaitu pejabat dan pegawai bank. Sedangkan unsur objektif, meliputi kegiatan penyelenggaraan tran-sper dana tanpa izin (pasal 79), mengambil atau memindahkan sebagian atau seluruh dana milik orang lain dengan perintah transper dana palsu (pasal 81), mengubah, menghilangkan atau menghapus sebagian atau seluruh informasi yang tercantum dalam perintah transper dana (pasal 83) dan merusak sistem transper dana (pasal 84).

Terpenuhinya semua unsur subjektif dan unsur- unsur objektif dari tindak pidana yang berkaitan dengan transper dana melalui lembaga perbankan, maka pelakunya baik orang luar dan orang di dalam bank dapat dijerat dengan ketentuan pasal 79, pasal 81, pasal 83 dan pasal 84. Di dalam ketentuan pasal 84 Undang- undang Transper Dana Nomor 3 Tahun 2011, terhadap pelaku yang melawan hukum dengan merusak sistem transper dana dapat dijerat dengan ancaman pidana maksimal penjara 20 tahun atau denda maksimal dua puluh milyar rupiah.

\section{E. Kesimpulan}

Berdasarkan uraian pembahasan yang diutarakan di atas, maka dapat ditarik beberapa kesimpulan, sebagai berikut ;

1. Faktor internal yang mempengaruhi perlunya dilakukan kebijakan regulasi dalam penanggulangan tindak pidana di bidang perbankan, mengingat ketentuan yang mengatur tentang tindak pidana di bidang perbankan dalam pasal 46 hingga pasal 50A Undang- undang Perban-kan Nomor 10 Tahun 1998, belumlah sepenuhnya dapat menampung berbagai jenis dan modus kejahatan/tindak pidana di bidang perban-kan yang terjadi dalam praktiknya, masih terdapat kelemahan dan atau kekurangan, sehingga perlu dilakukan penyempurnaan dan atau revisi/perbaikan terhadap Undangundang Perbankan Nomor 10 Tahun 1998 tersebut.

2. Faktor ekternal yang mempengaruhi perlu dilakukan kebijakan regu-lasi dalam penanggulangan tindak pidana di bidang perbankan, ada-lah di samping tindak pidana di bidang perbankan diatur dalam Un-dang- undang Perbankan Nomor 10 Tahun 1998, maka langkah anti-sipasi untuk melengkapi ketentuan Undang- undang Perbankan, diatur pula di luar ketentuan Undang- undang Perbankan Nomor 10 Tahun 1998, seperti yang dituangkan dan diatur di dalam Kitab Un-dang- undang Hukum Pidana (KUHP), Undang- undang Pemberan-tasan Tindak Pidana Korupsi, Undang- undang Penanaman Modal, Undang- undang Pencegahan dan Pemberantasan Tindak Pidana Pen-cucian 
Uang, Undang- undang Informasi dan Transaksi Elektronik dan Undang- undang Transper Dana.

\section{F. Rekomendasi}

Memperhatikan beberapa temuan di dalam pembahasan ini, sehingga ada beberapa rekomendasi yang dianggap penting untuk diperhatikan, yaitu ;

1. Perlu dilakukan penyempurnaan melalui revisi dan atau perbaikan dengan melakukan kebijakan regulasi terhadap beberapa ketentuan yang belum diatur dan dirumuskan di dalam ketentuan Undang- undang perbankan Nomor 10 Tahun 1998, dalam rangka antisipasi terhadap perkembangan kejahatan/tindak pidana di bidang per-bankan yang terjadi dengan menggunakan tehnologi yang cukup canggih di masa sekarang dan akan datang.

2. Perlu dilakukan sinkronisasi dan harmonisasi aturan dalam Un-dang- undang Perbankan Nomor 10 Tahun 1998 dengan Undang- undang lainnya yang berkaitan dengan kegiatan operasional per-bankan, sehingga dapat mempercepat kinerja aparat penegak hu-kum dalam upaya pemberantasan dan penanggulangan tindak pidana di bidang perbankan.

\section{G. Daftar Pustaka}

Barda Nawawi Arief, Kapita Selekta Hukum Pidana, PT. Citra Aditya Bakti : Bandung, 2010.

Hermansyah, Hukum Perbankan Nasional Indonesia,Kencana : Jakarta, 2009,

H. Zainuddin Ali, Metode Penelitian Hukum, Sinar Grafika : Jakarta, 2009.

H.A.K. Moch. Anwar, Tindak Pidana di Bidang Perbankan, Alumni : Bandung, 1986.

Kasmir, Bank dan lembaga Keuangan Lainnya, PT. RajaGrafindo Persada : Jakarta, 2013.

Kusumaningtuti Sandriharmy, Peranan Hukum Dalam Penyelesaian Krisis Perbankan di Indonesia, PT. RajaGrafindo Persada : Jakarta, 2009.

Kristian dan Yopi Gunawan, Tindak Pidana Perbankan, Nuansa Aulia : Bandung, 2013.

Marwan Effendi, Tipologi Kejahatan Perbankan Dari Perspektif Hukum Pidana, CV. Sumber Ilmu Jaya : Jakarta, 2005.

Marulak Pardede, Hukum Pidana Bank, Pustaka Sinar Harapan : Jakarta, 1995.

Muhama Djumhana, Muhammad Djumhana, Hukum Perbankan di Indonesia, PT.Citra Aditya Bakti : Bandung, 2000.

Munir Fuady, Bisnis Kotor, Anatomi Kejahatan Kerah Putih, PT.Citra Aditya Bakti : Bandung, 2004.

Munir Fuady, Hukum Perbankan Modern Buku Kesatu, Pt. Citra Aditya Bakti : Bandung, 2003.

Muhammad Djumhana, Hukum Perbankan di Indonesia, PT.Citra Aditya Bakti : Bandung, 2000 . 
M. Arief Amrullah, Politik Hukum Pidana Dalam Perlindungan Korban Kejahatan Peter Mahmud Marzuki, 2006, Penelitian Hukum, Kencana : Jakarta, 2002.

M. Sholehuddin, Sistem Sanksi Dalam Hukum Pidana : Ide Dasar Doble Track Sistem dan Implementasinya, PT. RajaGrafindo Persada : Jakarta, 2003.

Rachmadi Usman, Aspek- aspek Hukum Perbankan di Indonesia, PT.Gramedia Pustaka Utama : Jakarta, 2001.

Sutan Remy Sjahdeini, Pertanggungjawaban Pidana Korporasi, Grafiti Pers : Jakarta, 2006.

Supanto, Kejahatan Ekonomi Global dan Kebijakan Hukum Pidana, Alumni : Bandung, 2010.

Widjanarto, Hukum dan Ketentuan Perbankan di Indonesia, Grafiti : Jakarta, 2005.

Yunus Husein, Rahasia Bank dan Penegakan Hukum, Pustaka Juanda Tiga Lima : Jakarta, 2010.

Yusuf Shofie, Perlindungan Konsumen dan Instrument- instrument Hukumnya, PT. Citra Aditya Bakti : Bandung, 2009.

Yunan Sawidji, Kebijakan Penal Indonesia Terhadap Kejahatan Teroganisir, Fak. Hukum UGM : Jogyakarta, 1996.

Zulkarnaen Sitompul, Problematika Perbankan, Books Terrrance \&Library : Bandung, 2005.

Zudan Arif Fakrulloh, Ilmu Lembaga dan Pranata Hukum (Sebuah Pencarian), PT.RajaGrafindo Persada : Jakarta, 2011. 